\title{
Prevalence and Predictors of Occult Hepatitis C Infection in High-Risk Egyptian Populations
}

\author{
Mohammad M Sallam ${ }^{1}$, Hanan S Ahmed ${ }^{2}$, Hanan H Soliman³, \\ Sameh M. Abdel Monem ${ }^{4}$, Essam A Wahab ${ }^{1}$ \\ ${ }^{1}$ Hepatogastroenterology Unit, Department of Internal Medicine, Faculty of Medicine, \\ Zagazig University, Egypt. \\ ${ }^{2}$ Department of Clinical Pathology, Faculty of Medicine, Zagazig University, Egypt. \\ ${ }^{3}$ Department of Public health, Community, Environment and Occupational Medicine, \\ Faculty of Medicine, Suez Canal University, Egypt. \\ ${ }^{4}$ Department of Tropical Medicine, Faculty of Medicine, Zagazig University, Egypt.
}

Corresponding Author Sameh Mahmoud abdel Monem

Mobile:01000641647

E mail: drsameh154@yahoo.c om

Key words:

Hepatitis $C$ virus; Direct-acting antiviral agents; Occult $\mathrm{HCV}$ infection; PBMCs
Background and study aim: Direct acting antiviral agents (DAAs) altered hepatitis $\mathrm{C}$ virus (HCV) outcomes with a permanent cure in $90 \%$ of cases. However, HCV had not wiped out from all cases $(1 \% \sim 15 \%)$, which represent occult HCV infection (OCI). The aim of this study is to detect prevalence and predictors of OCI in four high-risk groups.

Patients and Methods: 196 participants were enrolled and assigned into four patients groups and one control group; group I (cryptogenic hepatitis), group II (HCV), group III (chronic HBV), group IV (ESRD), and group V (control group). HCV RNA testing in serum and in peripheral blood mononuclear cells, hepatic stiffness estimation and FIB-4 score calculation were done for all participants.

Results: Significant differences were found among different study groups regarding frequencies of HTN $(\mathrm{p}<0.001)$ and DM $(p<0.001)$, history of blood transfusion $(p<0.001)$, history of previous surgery $(p<0.001)$, as well as mean values of FIB-4 $(\mathrm{p}<0.001)$ and fibroscan readings $(\mathrm{p}=0.002)$. OCI was found in 25 participants (12.7\%), with different prevalence rates in different groups; being highest in group I (11/43, 25.3\%), followed by group III $(6 / 30,20 \%)$. Among all participants, OCI was significantly associated multiple risk factors that include; history of blood transfusion $(\mathrm{p}=0.004)$, previous surgery $(\mathrm{p}=0.017)$, positive family history of $\mathrm{HCV}$ infection $(\mathrm{p}<0.001)$, advanced fibrosis $(\mathrm{p}$ $=0.015)$ and high FIB-4 score $(\mathrm{p}=0.016)$. Positive family history of $\mathrm{HCV}$ infection and history of blood transfusion were considered as independent predictors for OCI.

Conclusion: Testing for OCI in high-risk populations and retesting in SVR cases might be needed to help in complete eradication of chronic $\mathrm{HCV}$ infection.

\section{INTRODUCTION}

Viral hepatitis is a common cause of mortality worldwide with hepatitis $\mathrm{C}$ virus (HCV) accounting for about half of this mortality [1]. Although HCV infection is a global public health problem, Middle East and North Africa (MENA) are the most affected regions [2]. Egypt still has the highest HCV prevalence worldwide in different population groups, with evidence for continuous $\mathrm{HCV}$ transmission. Health care may be the culprit of past and present $\mathrm{HCV}$ transmission, with about half of individuals belonging to the clinical populations at high-risk being infected. Genotype variation in Egypt is low, with genotype 4 being the dominant genotype [3]. Two thirds of $\mathrm{HCV}$ positive Egyptians are chronically infected and in need of treatment. With progressive scaling up DAAs treatment program, Egypt is likely to make ambitious steps towards HCV eradication by 2030 [4]. $\mathrm{HCV}$ is a single stranded ribonucleic acid (RNA) virus belonging to Flaviviridae family $[\mathbf{5 , 6}]$. Although 
$\mathrm{HCV}$ is a primary hepatotropic virus, its replication was reported in different extrahepatic cells, notably in peripheral blood mononuclear cells (PBMC) $[\mathbf{7 , 8}]$. Occult HCV infection (OCI) means detectable HCV RNA in the liver or PBMCs in the absence of detectable serum HCV RNA [12]. HCV replication in PBMCs may be the source of recurrent $\mathrm{HCV}$ infection after antiviral treatment or liver transplantation $[\mathbf{9 , 1 0}$. OCI was first reported by Pham et al. [11] in anti-HCV positive patients who recovered after a self-limited HCV infection and in patients who attained sustained virological response (SVR) due to interferon (IFN) treatment who had normal liver enzyme. In the same year, Castillo et al. [12] reported HCV RNA presence in anti$\mathrm{HCV} \mathrm{Ab}$ negative patients with elevated liver enzymes. There are two forms of OCI; cryptogenic(primary) OCI with persistently moderately elevated liver enzymes and negative serum anti-HCV Ab and HCV RNA $[13,14]$ and secondary OCI in patients with spontaneous or treatment-induced HCV RNA clearance from serum (positive anti $\mathrm{HCV} \mathrm{Ab}$, negative serum $\mathrm{HCV}$ RNA and normal liver transaminases) [15].The gold standard for the diagnosis of OCI depends mainly on detection of HCV RNA in hepatocytes, however, because of the invasive nature of liver biopsy, other alternatives were suggested as HCV RNA detection in the PBMCs, especially, when liver biopsy is not feasible [16].The consequences of OCI include risk for $\mathrm{HCV}$ transmission especially in hemodialysis units and with blood donation, in addition to the impact of OCI on the liver itself, where it may evolve to liver cirrhosis and hepatocellular carcinoma [17]. Early detection of OCI in high-risk groups and controlling its transmission are integral to improve life quality and more specifically lead to avoidance of liver complications such as liver decompensation and hepatic malignancies, and to a reduction in associated health costs burden. The aim of this study was to detect the predictors of OCI diagnosed by detecting HCV RNA replication in PBMCs in four high-risk groups ; those with asymptomatic sustained elevation of liver enzymes of unknown causes, those who gained SVR six months after the end of treatment with DAAs, patients with chronic HBV infection (CHB) and those with end stage renal disease (ESRD) on regular hemodialysis.

\section{PATIENTS AND METHODS}

\section{Study design and settings:}

This study carried in hepatogastroenterology unit, internal medicine department in collaboration with tropical medicine and clinical pathology departments, faculty of medicine, Zagazig University, Egypt, through one-year duration from March 2019 to February 2020.

\section{Target population and patients classification:}

After fulfilling inclusion and exclusion criteria, a total number of 196 participants were included. All participants had undetectable HCV RNA using peripheral blood PCR technique. After randomization, participants were distributed into four patients groups (high $\mathrm{HCV}$ infection risk) and a fifth control group. Group I (cryptogenic hepatitis, $n=43$ ), included patients with persistent liver enzymes elevation without obvious causes, group II (Post HCV treatment, $\mathrm{n}=58$ ), included chronic HCV patients with or without cirrhosis who achieved SVR12 with DAAs therapy, group III (Chronic hepatitis $\mathrm{B}, \mathrm{n}=30$ ), included overt CHB patients with or without cirrhosis, currently receiving nucleoside analogue therapy, group $I V$ (ESRD, $\mathrm{n}=35$ ), included ESRD patients on regular HD, and group $\boldsymbol{V}$ (Control group, $\mathrm{n}=30$ ) who were randomly selected from apparently healthy blood donors.

\section{Inclusion and exclusion criteria:}

Chronic HCV patients who achieved SVR with DAAs, chronic HBV under oral treatment, ESRD patients under regular HD and cryptogenic hepatitis (patients who have two folds or more elevation of both alanine aminotransferase (ALT) and aspartate aminotransferase (AST) of unknown cause for more than three months) were included in the study. For patients to be diagnosed as a case of cryptogenic hepatitis, she/he should have negative serum results for ; HCV Ab, HCV RNA, anti-HAV IgM, HBsAg, HBV-DNA, HBsAg, antibodies to other infections e.g. herpes simplex virus, cytomegalovirus, toxoplasma gondii and rubella, antinuclear antibody, antiliver-kidney microsomal antibody, antismooth muscle antibody and anti-mitochondrial antibody, as well as, normal serum levels of Alfa-fetoprotein, ferritin, and ceruloplasmin, and absence of hyperlipidemia with hepatomegaly, current drug abuse and alcohol intake. 


\section{Study tools:}

All participants were subjected to history taking, clinical examination and routine laboratory work- up [e.g. complete blood picture (CBC), fasting blood sugar (FBS), liver function tests and serum creatinine and blood urea], PCR for $\mathrm{HCV}$ RNA detection in serum and in PBMCs and pelviabdominal ultrasonography for assessment of liver, spleen and detection of ascites. Liver stiffness estimation was done by measuring the velocity of elastic shear waves of liver parenchyma generated by the mechanical push (Using Phillips IU22). The medium reading of the tissue elasticity was calculated and expressed in $\mathrm{kPa}$. FIB-4 score was calculated according to the formula; Age [years] $\times$ AST $[\mathrm{IU} / \mathrm{L}] /\left(\mathrm{PLT}\left[10^{9} / \mathrm{L}\right] \times\right.$ ALT $\left.[\mathrm{IU} / \mathrm{L}]^{1 / 2}\right)$; a score $>3.25$ was used as a threshold value for the diagnosis of advanced fibrosis and cirrhosis (F3 and F4) while a score $<1.45$ was used as a threshold value for no or early fibrosis (F0, F1). Peripheral blood mononuclear cells (PBMCs) isolation and detection of HCV RNA was done by quantitative realtime PCR in three steps: PBMC isolation, RNA extraction from PBMCs and HCV amplification by real time PCR (8).

\section{Data processing and analysis:}

All statistical calculations were done using SPSS (Statistical Package for the Social Science; SPSS Inc., Chicago, IL, USA version 18). Qualitative data were represented as frequencies and relative percentages. Chi square test $(\chi 2)$ and Fisher exact was used to calculate differences between qualitative variables as indicated. Quantitative data were expressed as mean \pm SD (Standard deviation). Independent $\mathrm{T}$ test and one-way analysis of variance (ANOVA) test were used to calculate differences between normally distributed quantitative variables in two groups or in more than two groups, respectively. A significance Level ( $p$ value) of $\leq 0.05$ indicates significant result.

\section{RESULTS}

Significant differences were encountered regarding the clinic-demographic features and laboratory data of the participants among different study groups including frequencies of HTN $(p<0.001)$, DM $(p<0.001)$, history of blood transfusion $(p<0.001)$, history of previous surgery $(\mathrm{p}<0.001)$, as well as mean values of ALT $\quad(p<0.001), \quad$ AST $\quad(\mathrm{p}<0.001), \quad$ serum creatinine $(p<0.001)$, FIB-4 $(p<0.001)$ and fibroscan readings $(\mathrm{p}=0.002)$ (table 1). $\mathrm{HCV}$ RNA was detected in PBMCs (representing OCI) in 25 out of $196(12.7 \%)$ participants. The prevalence rates of OCI in all groups were 11/43 $(25.3 \%)$ in group I, $5 / 58(8.6 \%)$ in group II, $6 / 30$ $(20 \%)$ in group III, $2 / 35(5.7 \%)$ in group IV and $1 / 30(3.3 \%)$ in control group (figure 1). After exclusion of confounders factors, all possible risk factors for OCI were tested in all participants, and OCI was significantly considered with the following risk factors; history of blood transfusion $(p=0.004)$, previous surgery $(p=0.017)$, positive family history of overt HCV infection $(p<0.001)$, advanced F4 fibrosis $(p=0.015)$ and high FIB-4 score $(p=0.016)$ (table 2). By logistic regression analysis, the significant independent predictors of OCI were positive family history of overt HCV infection $(p=0.002)$ and history of blood transfusion $(p=0.015)$ (table 3). 
Table (1): Basic demographic, clinical and laboratory features in different study groups

\begin{tabular}{|c|c|c|c|c|c|c|}
\hline & $\begin{array}{l}\begin{array}{l}\text { Group I } \\
(\mathrm{n}=43)\end{array} \\
\end{array}$ & $\begin{array}{c}\begin{array}{c}\text { Group II } \\
(\mathrm{n}=58)\end{array} \\
\end{array}$ & $\begin{array}{c}\text { Group III } \\
(\mathrm{n}=30)\end{array}$ & $\begin{array}{c}\text { Group IV } \\
(\mathrm{n}=35)\end{array}$ & $\begin{array}{c}\text { Group V } \\
(\mathrm{n}=30)\end{array}$ & $p$ \\
\hline Age (mean \pm SD, years) & $43.6 \pm 6.8$ & $43.7 \pm 7.2$ & $43.0 \pm 6.2$ & $44.5 \pm 6.4$ & $41.2 \pm 5.5$ & 0.338 \\
\hline Males & $26(60.50 \%)$ & $37(63.80 \%)$ & $24(80.00 \%)$ & $21(60.00 \%)$ & $15(50.00 \%)$ & 0.189 \\
\hline BMI (mean \pm SD) & $26.1 \pm 4.3$ & $25.6 \pm 3.9$ & $25.1 \pm 3.6$ & $26.2 \pm 2.8$ & $24.7 \pm 3.3$ & 0.392 \\
\hline HTN & $2(4.70 \%)$ & $1(1.70 \%)$ & $3(10.00 \%)$ & $30(85.70 \%)$ & $3(10.00 \%)$ & $<0.001$ \\
\hline$\overline{\mathrm{DM}}$ & $6(14.00 \%)$ & $6(10.30 \%)$ & $2(7.60 \%)$ & $29(82.90 \%)$ & $4(13.30 \%)$ & $<0.001$ \\
\hline ESRD on HD & $0(0.00 \%)$ & $0(0.00 \%)$ & $0(0.00 \%)$ & $35(100.0 \%)$ & $0(0.00 \%)$ & $<0.001$ \\
\hline History of blood transfusion & $8(18.60 \%)$ & $6(10.30 \%)$ & $3(10.00 \%)$ & $35(100.00 \%)$ & $3(10.00 \%)$ & $<0.001$ \\
\hline History of surgery & $9(20.90 \%)$ & $11(19.00 \%)$ & $8(26.70 \%)$ & $35(100.0 \%)$ & $5(16.7 \%)$ & $<0.001$ \\
\hline Positive family history & $9(20.90 \%)$ & $10(17.20 \%)$ & $5(16.70 \%)$ & $7(20.00 \%)$ & $7(20.00 \%)$ & 0.985 \\
\hline ALT (mean \pm SD, IU/L) & $88.9 \pm 21.9$ & $30.2 \pm 14.0$ & $32.1 \pm 14.0$ & $34.2 \pm 9.2$ & $32.9 \pm 13.9$ & $<0.001$ \\
\hline AST (mean/SD, IU/L) & $90.0 \pm 23.5$ & $33.6 \pm 10.1$ & $33.8 \pm 9.7$ & $34.1 \pm 6.9$ & $34.2 \pm 9.6$ & $<0.001$ \\
\hline $\begin{array}{l}\text { Total bilirubin } \quad(\text { mean } \pm \text { SD, } \\
\mathrm{mg} / \mathrm{dl})\end{array}$ & $0.92 \pm 0.17$ & $0.91 \pm 0.16$ & $0.92 \pm 0.19$ & $0.91 \pm 0.20$ & $0.93 \pm 0.17$ & 0.970 \\
\hline Albumin $($ mean $\pm S D, g / d l)$ & $4.09 \pm 0.39$ & $4.10 \pm 0.39$ & $4.04 \pm 0.38$ & $4.11 \pm 0.41$ & $4.02 \pm 0.42$ & 0.823 \\
\hline INR $($ mean \pm SD) & $1.12 \pm 0.11$ & $1.11 \pm 0.09$ & $1.09 \pm 0.09$ & $1.09 \pm 0.09$ & $1.08 \pm 0.08$ & 0.456 \\
\hline $\mathrm{Hb}(\mathrm{mean} \pm \mathrm{SD}, \mathrm{g} / \mathrm{dl})$ & $12.6 \pm 1.1$ & $12.8 \pm 1.1$ & $12.2 \pm 1.2$ & $12.6 \pm 1.3$ & $12.5 \pm 1.2$ & 0.286 \\
\hline Platelets $\left(\right.$ mean $\left.\pm \mathrm{SD}, \times 10^{3} / \mathrm{ml}\right)$ & $198.6 \pm 66.49$ & $190.24 \pm 55.43$ & $196.23 \pm 57.64$ & $199.66 \pm 57.48$ & $200.43 \pm 62.65$ & 0.911 \\
\hline Creatinine $($ mean \pm SD, $\mathrm{mg} / \mathrm{dl})$ & $0.97 \pm 0.20$ & $0.96 \pm 0.19$ & $0.88 \pm 0.30$ & $10.44 \pm 2.13$ & $0.75 \pm 0.19$ & $<0.001$ \\
\hline FIB-4 (mean \pm SD) & $2.09 \pm 1.60$ & $2.13 \pm 1.61$ & $2.31 \pm 1.73$ & $1.25 \pm 0.81$ & $1.01 \pm 0.17$ & $<0.001$ \\
\hline $\begin{array}{l}\text { Liver cirrhosis (F4 by } \\
\text { fibroscan) }\end{array}$ & $9(20.9 \%)$ & $15(25.9 \%)$ & $10(33.3 \%)$ & $2(5.7 \%)$ & $0(0.0 \%)$ & 0.002 \\
\hline HCV Ab positivity & $0(0.0 \%)$ & $58(100.0 \%)$ & $0(0.0 \%)$ & $0(0.0 \%)$ & $0(0.0 \%)$ & $<0.001$ \\
\hline $\begin{array}{l}\text { Pretreatment HCV- RNA } \\
\text { (median, IU/HPF) }\end{array}$ & - & 515433.0 & - & 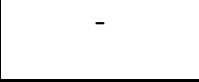 & - & - \\
\hline $\begin{array}{lll}\text { Current } & \text { HCV } & \text { RNA } \\
(\text { mean } \pm S D, & \text { IU } / H P F)\end{array}$ & undetectable & undetectable & undetectable & undetectable & undetectable & - \\
\hline HBsAg positivity & $0(0.0 \%)$ & $0(0.0 \%)$ & $30(100.0 \%)$ & $0(0.0 \%)$ & $0(0.0 \%)$ & $<0.001$ \\
\hline HBeAg positivity & - & - & $26(86.7 \%)$ & & - & - \\
\hline HBV DNA (median, IU/HPF) & - & - & 436036.0 & - & - & - \\
\hline $\begin{array}{l}\text { Positive HCV replication In } \\
\text { PBMC (OCI) }\end{array}$ & $11(25.6 \%)$ & $5(8.6 \%)$ & $6(20.0 \%)$ & $2(5.7 \%)$ & $1(3.3 \%)$ & 0.013 \\
\hline
\end{tabular}

Table (2): Possible OCI predictors in all participants

\begin{tabular}{|l|c|c|c|}
\hline & $\begin{array}{c}\text { No OCI } \\
(\mathrm{n}=171)\end{array}$ & $\begin{array}{c}\text { OCI } \\
(\mathrm{n}=25)\end{array}$ & $p$ \\
\hline Age (mean \pm SD, years) & $43.50 \pm 6.64$ & $42.00 \pm 6.18$ & 0.286 \\
\hline Male gender & $106(62.00 \%)$ & $17(68.00 \%)$ & 0.561 \\
\hline BMI (mean \pm SD) & $25.57 \pm 3.64$ & $25.90 \pm 3.94$ & 0.676 \\
\hline HTN & $35(20.50 \%)$ & $4(16.00 \%)$ & 0.601 \\
\hline DM & $41(24.00 \%)$ & $6(24.00 \%)$ & 0.998 \\
\hline History of blood transfusion & $42(24.60 \%)$ & $13(52.00 \%)$ & 0.004 \\
\hline History of surgery & $54(31.60 \%)$ & $14(56.00 \%)$ & 0.017 \\
\hline Positive family history & $26(15.20 \%)$ & $11(44.00 \%)$ & $<0.001$ \\
\hline Total bilirubin $($ mean \pm SD, mg/dl) & $0.91 \pm 0.18$ & $0.94 \pm 0.15$ & 0.514 \\
\hline Serum albumin $(\mathbf{m e a n} \pm$ SD, g/dl) & $4.09 \pm 0.39$ & $3.99 \pm 0.42$ & 0.226 \\
\hline INR $($ mean \pm SDD) & $1.10 \pm 0.09$ & $1.13 \pm 0.10$ & 0.096 \\
\hline Hb $($ mean \pm SD, g/dl) & $12.67 \pm 1.20$ & $12.24 \pm 0.87$ & 0.087 \\
\hline Platelets (mean \pm SD, x10 $\mathbf{3} / \mathbf{m l})$ & $196.58 \pm 58.23$ & $193.88 \pm 67.67$ & 0.832 \\
\hline FIB-4 score $(\mathbf{m e a n} \pm$ SD) & $1.72 \pm 1.36$ & $2.47 \pm 1.87$ & 0.016 \\
\hline Liver fibroscan: F4 & $27(15.80 \%)$ & $9(36.00 \%)$ & 0.015 \\
\hline
\end{tabular}


Table (3): Logistic regression analysis of OCI predictors

\begin{tabular}{|l|c|c|c|c|}
\hline \multicolumn{1}{|c|}{ Predictor } & \multirow{2}{*}{ Expected (B) } & \multicolumn{2}{c|}{$95 \%$ CI of expected (B) } & \multirow{2}{*}{$p$} \\
\cline { 3 - 5 } & & Lower bound & Upper bound & \\
\hline History of blood transfusion & 0.218 & 0.064 & 0.744 & 0.015 \\
\hline History of surgery & 0.767 & 0.248 & 2.370 & 0.644 \\
\hline Positive family history & 0.218 & 0.082 & 0.576 & 0.002 \\
\hline FIB-4 score & 1.238 & 0.583 & 2.629 & 0.579 \\
\hline Liver fibroscan (F4) & 0.428 & 0.028 & 6.632 & 0.544 \\
\hline
\end{tabular}

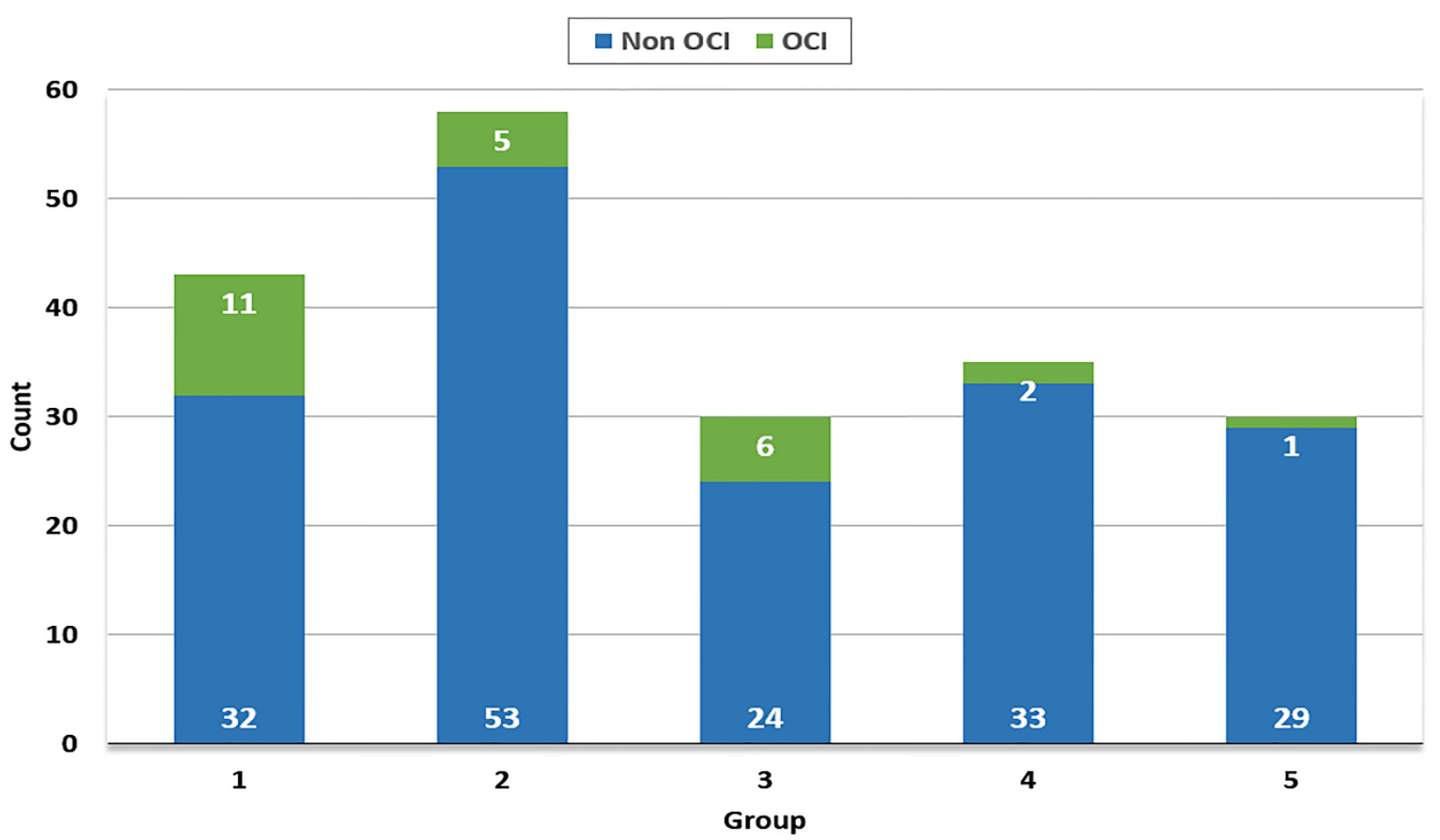

Figure 1: Frequency of OCI cases in all study groups

\section{DISCUSSION}

$\mathrm{HCV}$ can infect extrahepatic organs in addition to the liver particularly PBMCs which represent reservoirs for $\mathrm{HCV}$ that are potentially responsible for OCI development [18]. OCI is a neglected issue of HCV infection, little is known about its prevalence, natural history, potential transmission risk, and impact on the general population. It has been suggested OCI patients are potentially infectious, and they have a better immune reaction that could be the cause of milder disease compared to patients with overt hepatitis C [19]. Several Egyptian studies declared the prevalence of OCI in different patients groups; healthy partners of $\mathrm{HCV}$ infected patients $(4 \%)$, patients with cryptogenic hepatitis $(40.7 \%)$, patients with non-alcoholic fatty liver disease $(40.7 \%)$, those with chronic lymphoproliferative disorder $(20 \%)$ and in patients under HD (3.7\%) [20-24]. We studied
OCI in four groups of Egyptian populations with high $\mathrm{HCV}$ infection risk. OCI (positive $\mathrm{HCV}$ RNA in PBMCs) was discovered in 25 out of 196 participants with an overall prevalence of $12.7 \%$, and patients with cryptogenic hepatitis (group I) had the highest prevalence (11/43, 25.6\%). Similar findings and percentages reported by Makvandi et al. [25] and Yahia et al. [26], who detected HCV RNA in PBMCs in 32 $\%$ and $25 \%$ of patients with unexplained persistently abnormal liver function test results, respectively. The higher prevalence of OCI in cryptogenic hepatitis (61\%) that reported by Castillo et al. [27] may be related to the different methods used, as Castillo et al., detected HCV RNA in PBMCs by using a highly specific RTPCR assay. Our findings didn't go in harmony with that of Halfon et al., who concluded that OCI cannot be found in PBMCs of patients with cryptogenic liver diseases. Halfon's results may be explained by improper storage of PBMCs

Sallam et al., Afro-Egypt J Infect Endem Dis 2020;10(4):364-372

https://aeji.journals.ekb.eg/

http://mis.zu.edu.eg/ajied/home.aspx 
samples which may hinder viral RNA detection, low sensitivity of the technique used, and the too small sample size [28]. With the introduction of DAAs therapy for HCV infection, 90\% 95\% of treated patients achieved SVR, however, a considerable percent of patients has experienced relapses later. Posttreatment persistence of intracellular OCI possibly acts as a reservoir and might be related to later viral relapse [29]. In (group II) of current study, out of 58 studied patients who received DAAs and achieved SVR12, five patients $(8.6 \%)$ had positive $\mathrm{HCV}$ BRNA in their PBMC, six months after the end of therapy. A prevalence rate near to ours (11.3\%) was found in a similar patient population by Yousif et al. [30]. A recent Egyptian study conducted by AbdAlla and ElAwady reported a relatively higher prevalence of OCI (18\%) using PBMCs PCR in sustained DAAs responders [29]. Higher prevalence rates were reported by Gallegos-Orozco et al. [31], Zayed et al. [32], Hanno et al. [33] and Radkowski et al. [34] who detected HCV RNA in PBMCs in $20 \%, 27 \%, 32 \%$ and $88 \%$ of patients who developed SVR after successful DAAs therapy, respectively. The great difference between our results and that of Rakowski et al., may be attributed to three explanations: first one; the detection of occult HCV RNA in our study was related only to PBMCs but in that of Radkowski et al., it was related to three components (serum, PBMC, or tissue), second one; our study was designed to follow patients up to 6 months only, while, Radkowski et al., followed their patients up to 9 years, and lastly, the treatment regimen in Rakowski's study was pegylated interferon(INF)/ribavirin combination. On the other hand, Maylin et al. [35] could not detect OCI in successfully treated patients with INF-based therapy. The association of active $\mathrm{HBV}$ and OCI is very interesting and needs to be thoroughly investigated. One of possible explanations for high prevalence of OCI among $\mathrm{CHB}$ patients is that active $\mathrm{HBV}$ have a modulating effect on immune system facilitating $\mathrm{HCV}$ persistence in PBMCs [36]. Also, HBV and $\mathrm{HCV}$ have common modes of transmission and thus, coinfection with $\mathrm{HBV}$ and $\mathrm{HCV}$ is not uncommon [37]. We detected OCI in six out of 30 patients with overt CHB (20\%), a prevalence that goes near to that reported by De Marco et al., (28\%) [36]. A higher prevalence of OCI in CHB patients (40\%), was reported by Castillo et al. [37], which may be explained by the higher yield of $\mathrm{HCV}$ RNA detection in the liver samples, used in their study. Appropriate detection of $\mathrm{HCV}$ infection (either overt or occult) among $\mathrm{CHB}$ patients can limit the spread of $\mathrm{HCV}$ infection by applying strict hygienic control measures [38]. Patients on regular HD have higher infection rates for $\mathrm{HCV}$ infection than the general population [39]. Detecting HCV infection in patients with ESRD is critical in the setting of future renal transplantation, where viral eradication before surgery is an important issue [40]. Reactivation of $\mathrm{HCV}$ after renal transplantation in recipients with OCI is another theoretical concern, because immunosuppressive therapy enhances $\mathrm{HCV}$ replication [41]. In current study, we detected two OCI cases out of 35 ESRD patients on regular HD (5.7\%), a percentage that is near to that of a study designed by Naghdi et al. [42], in which, six cases of OCI were diagnosed, by using the same method, out of 198 ESRD patients (3\%). On the other hand, higher prevalence was reported by El-Shishtawy et al. [43] Nahla et al. [44] (15.1\% and 9.7\%, respectively). We detected certain significant risk factors for OCI including history of blood transfusion $(p=0.004)$, history of previous surgery $(p=0.017)$, positive family history of OCI $(\mathrm{p}<0.001)$, high FIB-4 level $(\mathrm{p}=0.016)$, and advanced fibrosis (F4) by fibroscan $(\mathrm{p}=0.015)$. By using logistic regression analysis, the independent predictors for OCI were positive family history of overt HCV infection $(\mathrm{p}=0.002)$ and history of blood transfusion (p0.015). We found the risk of OCI after blood transfusion in all patients of HD group, $18.6 \%$ of cryptogenic hepatitis group, and in around $10 \%$ of other groups. Near to our results, El-Shishtawy et al. [43] and El-Rehewy et al. [45] found OCI in $62.5 \%$ and $74.7 \%$ of ESRD patients on regular HD, respectively. Moreover, Castello et al. [12] noticed that $9.5 \%$ of patients with OCI in the setting of $\mathrm{CHB}$ had history of blood transfusion and only $5 \%$ of patients with cryptogenic hepatitis who were proven to have OCI had a history of blood transfusion. Our results also showed that $54 \%$ of participants proven to have OCI, had history of previous surgery. We found positive family history of overt HCV infection as an independent predictor of OCI among all groups, being present in $44 \%$ of OCI patients and in $15.2 \%$ of those without OCI $(p<0.001)$. Similar results were reported in HD patients by El-Moselhy et al. [47] and El-Shishtawy et al. [43] Although OCI appears to be milder than classical chronic $\mathrm{HCV}$, it was also found in patients with cirrhosis and HCC which suggest

Sallam et al., Afro-Egypt J Infect Endem Dis 2020; 10 (4):364-372

https://aeji.journals.ekb.eg/

http://mis.zu.edu.eg/ajied/home.aspx 
that it can progress to more serious chronic hepatic injury. OCI also has been described in healthy population without evidence of liver disease [47]. In this study, $36 \%$ of OCI proven cases, had advanced fibrosis score (F4) as identified by fibroscan readings, and a significantly lower rate $(15.8 \%)$ was found among OCI free cases $(p=0.015)$. Similar findings were reported by Mekky et al. [48] who studied the prevalence and predictors of OCI among Egyptian patients who gained SVR after Sofosbuvir/Daclatasvir therapy where all their positive OCI cases had a significant fibrosis score (F3 or F4) by fibroscan. A considerable risk of OCI is present in patients with cryptogenic hepatitis, chronic HBV, SVR after DAAs therapy of HCV infection and in ESRD patients on regular HD. History of blood transfusion, positive family history of overt $\mathrm{HCV}$ infection are independent predictors for OCI. History of previous surgery and advanced fibrosis are other significant risk factors for OCI. We concluded that a considerable risk for OCI is present in high-risk populations as the positive cases might be a source of infection to others. The need for treatment of OCI must be evaluated in further studies.

\section{Conflict of interests: None}

\section{Funding: None}

Ethical consideration: Ethical clearance was obtained from the Ethical Board of the faculty of medicine, Zagazig University, Egypt. Oral consent was obtained from the participants after the consent form was developed by the research team and approved by the ethical committee. All information gathered from the clients was handled confidentially, and it was used only for the research purposes.

\section{REFERENCES}

1. Stanaway JD, Flaxman AD, Naghavi M, Fitzmaurice C, Theo Vos, Ibrahim Abubakar, et al. The global burden of viral hepatitis from 1990 to 2013; findings from the Global Burden of Disease Study 2013. Lancet. 2016; 388(10049):1081-88.

2. World Health Organization. Global viral hepatitis report. Geneva: World Health Organization, $2017 \quad$ (http://www.who.int/ hepatitis/publications/globalhepatitisreport2017/en).

3. World Health Organization. The epidemiology of hepatitis $\mathrm{C}$ virus in the World Health Organization eastern Mediterranean region: implications for strategic action. Eastern Mediterranean hepatitis C virus epidemiology synthesis project 2017.

4. Kouyoumjian SP, Chemaitelly $\mathrm{H}$, and AbuRaddad LJ. Characterizing hepatitis C virus epidemiology in Egypt: systematic reviews, meta-analyses, and meta-regressions. Scientific Reports 2018; 8:1661.

5. Carreño V. Occult hepatitis $\mathrm{C}$ virus infection: $\mathrm{A}$ new form of hepatitis C. World J Gastroenterol 2006; 12: 6922-25.

6. Khodir SA, Alghateb M, Okasha KM, ShalabySel-S. Prevalence of HCV infections among hemodialysis patients in Al Gharbiyah Governorate, Egypt. Arab J Nephrol Transplant 2012; 5:145-47.

7. Lindenbach BD, Rice CM. Flaviviridae; The viruses and their replication. In: Knipe DM, Howley PM, Griffin DE, et al. eds. Fields virology. $4^{\text {th }}$ ed. Philadelphia: Lippincott Williams \& Wilkins. 2001; 991-1041.

8. Chary A, Winters MA, Eisen R, Knight TH, Asmuth DM and Holodniy M. Quantitation of hepatitis $\mathrm{C}$ virus RNA in peripheral blood mononuclear cells in $\mathrm{HCV}$ monoinfection and HIV/HCV-coinfection. J Med Virol 2012; 84: 431-37.

9. Revie D and Salahuddin SZ. Human cell types important for hepatitis $\mathrm{C}$ virus replication in vivo and in vitro: old assertions and current evidence. Virol J 2011; 8:346.

10. Rezaee-Zavareh MS, Hadi R, Karimi-Sari H, Hossein Khosravi M, Ajudani R,and Dolatimehr F. Occult HCV Infection; the current state of knowledge. Iran Red Crescent Med J 2015; 17(11): e34181.

11. Pham TN, Parland SA, Patricia M., Mulrooney PM, Cooksley H, and Michalak TI. Hepatitis C virus persistence after spontaneous or treatmentinduced resolution of hepatitis C. J Virol 2004;78(11):5867-74.

12. Castillo I,Pardo M, Bartolomé J,Ortiz-Movilla N,Rodríguez-Inigo E, de Lucas S, et al. Occult hepatitis $\mathrm{C}$ virus infection in patients in whom the etiology of persistently abnormal results of liver function tests is unknown. Journal of Infectious Diseases 2004;189(1):7-14. 
13. Zaghloul H, and El-Sherbini W. Detection of occult hepatitis $\mathrm{C}$ and hepatitis $\mathrm{B}$ virus infections from peripheral blood mononuclear cells. Immunol Invest 2010; 39(3):284-91.

14. Barril G, Castillo I,Dolores Arenas M, Espinosa M, Garcia-Valdecasas J, Garcia-Fernández N, et al. Occult hepatitis $\mathrm{C}$ virus infection among hemodialysis patients. J Am Soc Nephrol 2008; 19(12):2288-92.

15. Pham TN, Coffin CS, Michalak TI. Occult hepatitis $\mathrm{C}$ virus infection: what does it mean? Liver Int 2010; 30(4):502-11.

16. Austria A, and Wu GY. Occult hepatitis $\mathrm{C}$ virus infection; A review. J Clin Transl Hepatol 2018; 6(2):155-60.

17. Bartolomé J, Manuel López-Alcorocho J, Castillo I, Rodríguez-Inigo E, Antonio Quiroga J, Palacios R,Vicente Carreño V. Ultracentrifugation of serum samples allows detection of hepatitis $\mathrm{C}$ virus RNA in patients with occult hepatitis C. J Virol 2007; 81(14): 7710-15.

18. Pham TN, Coffin CS, Churchill ND, Urbanski SJ, Lee SS, Michalak TI. Hepatitis C virus persistence after sustained virological response to antiviral therapy in patients with or without past exposure to hepatitis B virus. J Viral Hepat 2012; 19(2):103-11.

19. Lin H, Chen X, Zhu S, Mao P, Zhu S, Liu Y, Huang C, Sun J, and Zhu J. Prevalence of Occult Hepatitis C Virus Infection among blood donors in Jiangsu, China. Intervirology 2016; 59:20410.

20. El Shazly Y, Hemida K, Rafik M, Al Swaff R, Ali-Eldin ZA, GadAllah S. Detection of occult Hepatitis C virus among healthy spouses of patients with HCV infection. J Med Virol 2015; 87(3):424-27.

21. Saad Y, Zafer M, Amin M, Mai El-Daly, Mohamed Abdel Hamid, Gamal Esmat, et al. High prevalence of occult hepatitis $\mathrm{C}$ in Egyptian patients with cryptogenic hepatitis. Kasr El-Aini Medical Journal 2010;16(2).

22. Yasmin Saad, Soheir Zakaria, Iman Ramzy, Maissa El Raziky, Olfat Shaker, Wafaa elakel, et al. Prevalence of occult hepatitis C in Egyptian patients with non-alcoholics fatty liver disease. Open J Intern Med 2011; 1:33-37.

23. Youssef SS, Nasr AS, El Zanaty T, El Rawi RS, Mattar MM. Prevalence of occult hepatitis C virus in Egyptian patients with chronic lymphoproliferative disorders. Hepat Res Treat 2012; 2012:429784.
24. Abdulrahim SS, Khairy R, Esmail MA, Ragab M, Abdel-Hamid M, Abdelwahab SF. Occult Hepatitis C Virus Infection Among Egyptian Hemodialysis Patients. J Med Virol 2016; 88(8):1388-93.

25. Makvandi M, Khalafkhany D, Rasti M, Neisi N, Omidvarinia A, Mirghaed AT, Masjedizadeh A, Shyesteh AA. Detection of Hepatitis C virus RNA in peripheral blood mononuclear cells of patients with abnormal alanine transaminase in Ahvaz. Indian Journal of Medical Microbiology 2014; 32(3): 251-55.

26. Gad YZ, Mouas N, Abdel-Aziz A, Abousmra N, Elhadidy M. Distinct immunoregulatory cytokine pattern in Egyptian patients with occult Hepatitis C infection and unexplained persistently elevated liver transaminases. Asian J Transfus Sci 2012; 6(1): 24-28.

27. Castillo I, Rodríguez-Iñigo E, Bartolomé J, De Lucas S, Ortíz-Movilla N, López-Alcorocho JM, Pardo M, Carreño V. Hepatitis C virus replicates in peripheral blood mononuclear cells of patients with occult hepatitis C virus infection. Gut 2005; 54:682-85.

28. Halfon $\mathrm{P}$, Bourlière $\mathrm{M}$, Ouzan $\mathrm{D}$, Sène $\mathrm{D}$, Saadoun D, Khiri H, et al. Occult hepatitis C virus infection revisited with ultrasensitive real time PCR assay. J Clin Microbiol 2008; 46(6): 2106-108.

29. AbdAlla MDA, ElAwady MK. Hepatitis C virus RNA strands detection in peripheral blood mononuclear cells legitimizes virus eradication in negative serum PCR naive and posttreatment patients. J Clin Transl Hepatol 2017; 5(1):1-8.

30. Yousif MM, Fakhr AE, Morad EA, Kelani H, Hesham Kelani, Emad F Hamed, et al. Prevalence of occult hepatitis $\mathrm{C}$ virus infection in patients who achieved sustained virologic response to direct-acting antiviral agents. Le Infezioni in Medicina 2018; 3:237-43.

31. Gallegos-Orozco JF, Rakela J, Rosati MJ, Vargas HE, Balan V. Persistence of hepatitis C virus in peripheral blood mononuclear cells of sustained viral responders to pegylated interferon and ribavirin therapy. Dig Dis Sci 2008; 53(9):2564-68.

32. Zayed RA, Rushdy E, Saleh DA. Detection of HCV RNA in the peripheral blood mononuclear cells of serum HCV RNA - negative Egyptian patients under interferon treatment. Am J Med Sci 2010; 340:435-38.

33. Hanno AF, Mohiedden KM, Alshayeb AF, Deghedy A. HCV RNA in peripheral blood

Sallam et al., Afro-Egypt J Infect Endem Dis 2020; 10 (4):364-372

https://aeji.journals.ekb.eg/

http://mis.zu.edu.eg/ajied/home.aspx 
mononuclear cells (PBMCs) as a predictor of the response to antiviral therapy in chronic hepatitis C. Alexandria Journal of Medicine 2014; 50: 317-22.

34. Radkowski M, Gallegos-Orozco JF, Jablonska J, Colby TV, Bozena Walewska-Zielecka, Joanna Kubicka, et al. Persistence of hepatitis $\mathrm{C}$ virus in patients successfully treated for chronic hepatitis C. Hepatology 2005;41(1):106-14.

35. Maylin S, Martinot-Peignoux M, Moucari R, Nathalie Boyer, Marie-Pierre Ripault, Dominique Cazals-Hatem, et al. Eradication of hepatitis $\mathrm{C}$ virus in patients successfully treated for chronic hepatitis C. Gastroenterology 2008; 135(3):821-29.

36. De Marco L, Manzini P, Trevisan M, Anna Gillio-Tos, Franca Danielle, Cinzia Balloco, et al. Prevalence and follow-up of occult $\mathrm{HCV}$ infection in an Italian population free of clinically detectable infectious liver disease. PLOS ONE 7: e43541.

37. Castillo I, Bartolomé J, Quiroga JA, Carreño V. High prevalence of occult hepatitis $\mathrm{C}$ virus infection in patients with chronic hepatitis B virus infection. $J$ Med Microbiol 2013; 62(8):1235-38.

38. Fabrizi F, Martin P. Health care associated transmission of hepatitis $\mathrm{B}$ and $\mathrm{C}$ viruses in hemodialysis units. Clin Liver Dis 2010; 14:4960.

39. Fabrizi F, Bunnapradist S, Lunghi G, Aucella F, Martin P. Epidemiology and clinical significance of hepatotropic infections in dialysis patients; Recent evidence. J Minerva Urol Nefrol 2004; 56(3):249-57.

40. Baid AS, Schindler R, Reinke P, Adrienne Staedtler, Sunda Rimpler, Barbara Malik, et al. Prevalence of occult hepatitis $\mathrm{C}$ infection in chronic hemodialysis and kidney transplant patients. J Hepatol 2014; 60(5): 928-33.

41. Fabrizi F, Martin P. Occult hepatitis C virus infection in hemodialysis. JASN 2008; 19(12): 2248-50.
42. Naghdi R, Ranjbar M, Bokharaei-Salim F, Keyvani H, Savaj S, Ossareh S et al. Occult Hepatitis C Infection Among Hemodialysis Patients: A Prevalence Study. Ann Hepatol 2017;16(4):510-13.

43. El-Shishtawy S, Sherif N, Abdallh E, Laila Kamel, Mohamed Shemis, Abdel Aziz Ali Saleem, et al. Occult Hepatitis C Virus Infection in Hemodialysis Patients; Single Center Study. Electron Physician 2015; 7(8):1619-25.

44. Anber N, Abd El Salam M, Abd El Wahab AM, Zaki ME. RNA Prevalence of Occult Hepatitis C in Chronic Hemodialysis Patients in Mansoura University Hospital, Egypt. IJAPBC 2016; 5(1):73-78.

45. El-Rehewy MS, Sadek AA, Hamed HB, Tony EA, Amin MM, Yassin AS. Interleukin-10 level in Occult Hepatitis C Virus Infection in Hemodialysis Patient. Egyptian Journal of Medical Microbiology 2015; 24(2):39-43.

46. El-Moselhy EA, Abd El-Aziz A, Atlam SA, Raed H. Mnsour, Hesham H. Amin, Tarek H. Kabi et al. Prevalence and Risk Factors of Overtand Occult Hepatitis C Virus Infection among Chronic Kidney Disease Patients under Regular Hemodialysis in Egypt. The Egyptian Journal of Hospital Medicine 2015; 61:653- 69.

47. Carreño V, Bartolomé J, Castillo I, Quiroga JA. New perspectives in occult hepatitis $\mathrm{C}$ virus infection. World J Gastroenterol 2012;18 (23):2887-94.

48. Mekky MA, Sayed HI, Abdelmalek M, Medhat A Saleh, Osman A Osman, Heba A Osman et al. Prevalence and predictors of occult hepatitis C virus infection among Egyptian patients who achieved sustained virologic response to sofosbuvir/daclatasvir therapy: a multicenter study. Infection and Drug Resistance 2019; 12: 273-79. 